\title{
Abdominal or Transrectal Ultrasonographic Prostate Volume and Cystoscopic Prostatic Urethral Length Measurements to Determine the Surgical Technique for Prostatectomy in Patients with Benign Prostate Hyperplasia
}

\section{Benign Prostat Hiperplazisi Hastalarında, Prostatektomi için Cerrahi Tekniği Belirlemede, Abdominal veya Transrektal Ultrasonografik Prostat Hacmi ve Sistoskopik Prostatik Üretral Uzunluk Ölçümleri}

\author{
Aslan Demir1, Mert Ali Karadağ1, Kürşat Çeçen1, Levent Türkeri2 \\ ${ }^{1}$ Kafkas University Faculty of Medicine, Department of Urology, Kars, Turkey \\ 2Acıbadem University Faculty of Medicine, Department of Urology, İstanbul, Turkey
}

\section{What's known on the subject? and What does the study add?}

The prostate volume (PV) is the most important parameter while taking a decision about surgical technique in case of needed. The aim of this work is to determine the most accurate technique about PV between 3 techniques that we used. If succeded this, it can be gave more information about surgical technique and hospitalization process to the patients, and also the preparation of the operation room to the operation team.

\section{ABSTRACT}

Objective

We aimed to determine the most suitable technique for prostate volume (PV) measurement to decide for the most appropriate surgical approach - endoscopic or open - by establishing the relationship between imaging techniques and the resected tissue weight (RTW).

\section{Materials and Methods}

Sixty men aged 49-95 years with lower urinary tract symptoms, who were scheduled for transurethral resection, were enrolled. The relationship of RTW with PV determined by preoperative abdominal ultrasonography as well as transrectal ultrasonography (TRUS) performed at the table just before surgery, and prostatic urethral length (PUL) measured at the time of cystoscopy was analyzed. Two groups were established with respect to $\mathrm{PV}$, (less than or equal to $75 \mathrm{cc}$ and greater than $75 \mathrm{cc}$, respectively), and according to PUL (less than or equal to $2.5 \mathrm{~cm}$ and longer than 2.5 $\mathrm{cm}$, respectively). Statistical analyses were performed between the groups to identify the best correlation between resected tissue weight and presurgical volume determination methods.

\section{Results}

The strongest correlation between RTW and prostatic volume measurements was established for the TRUS measurements $(r=0.79 ; p<0.001)$. The coefficients of the abdominal and transrectal ultrasonographic volume and PUL were $0.127,0.287$ and 0.219 , respectively.
Öz

Amaç

Biz bu çalışmada, prostatektomi açısından en uygun cerrahi yaklaşıma -endoskopik veya açık- karar vermek için, görüntüleme teknikleri ve rezeke edilen doku ağırlığı arasındaki ilişkiyi kullanarak, prostat hacim ölçümleri için en uygun tekniği belirlemeyi amaçladık.

\section{Gereç ve Yöntem}

Transüretral rezeksiyon planlanan, alt üriner sistem yakınmaları bulunan, 49-95 yaşlarında 60 hasta çalışmamıza dahil edildi. Rezeke edilen doku ağırlığı, abdomimal ve cerrahi öncesi masada ölçülen transrektal ultrasonografi (TRUS) prostat boyutları ve sistoskopi esnasında ölçülen prostatik üretral uzunluk arasındaki ilişki incelendi. Prostat hacimleri açısından, 75 cc'den küçük eşit ve büyük ve de prostatik uzunluk ölçümlerine gore de $2,5 \mathrm{~cm}$ 'den kısa ve uzun olmak üzere 2 grup oluşturuldu. Bu iki grup arasında, rezeke edilen doku ağırlığı ve cerrahi öncesi hacim ölçüm yöntemleri arasında en iyi ilişki belirlemek için istatistiksel analiz yapıldı.

Bulgular

Rezeke edilen doku ağırlığı ile prostatik hacim ölçümleri arasındaki en güçlü ilişki TRUS ölçümleri ile olanla saptandı $(r=0,79 ; p<0,001)$. Abdominal ve TRUS prostat hacimleri ve prostatik üretra uzunluk katsayıları, sırasıyla, $0,127,0,287$ ve 0,219 idi.

\section{Correspondence}

Aslan Demir MD, Kafkas University Faculty of Medicine, Department of Urology, Kars, Turkey

Phone: +90 5324658225 E-mail: benaslandemir@yahoo.com.tr Received: 18.04.2016 Accepted: 22.08.2016

Presented in: $23^{\text {th }}$ Turkish Urological Congress 


\section{ABSTRACT}

\section{Conclusion}

Determination of PV by TRUS was found to be more accurate than abdominal ultrasonographic and cystoscopic measurements. Therefore, TRUS measurement of volume on the table at the time of surgery appears to be more suitable than other methods for the selection of the most suitable surgical technique especially in case of pre-operative difficulty for deciding the most appropriate surgical approach.

\section{Keywords}

Prostatectomy technique, transrectal ultrasonography, prostate volume, prostatic urethral length

\section{ÖZ}

\section{Sonuç}

Prostat volümlerinin TRUS ölçümleri, abdominal ultrasonik ve sistoskopik ölçümlerden, gerçek boyutlara daha yakın olarak saptadığı anlaşıldı. Dolayısıyla, cerrahinin hemen öncesinde masada bakılan, prostat hacminin TRUS ölçümlerinin belirlenmesi, diğer yöntemlere göre, özellikle en uygun cerrahi yaklaşımın belirlenmesi güç olgularda, cerrahi yöntem kararının verilmesinde daha uygun bir yol gibi görünmektedir.

\section{Anahtar Kelimeler}

Prostatektomi tekniği, transrektal ultrasonografi, prostat hacmi, prostatik üretral uzunluk

\section{Introduction}

Benign prostatic hyperplasia (BPH) is a chronic complex disease that is commonly associated with lower urinary tract symptoms (LUTS). Although benign, BPH often negatively affects health and quality of life (OoL). About 30\% of patients suffering from LUTS require surgery either because of insufficient palliative treatment with medication and/or disease progression (1). BPH is present in up to $50 \%$ of men over 60 years of age and nearly $88 \%$ of those 80 and older (2). Treatment options for BPH have expanded dramatically over the past two decades with the development of new strategies, including medical and minimally invasive treatments. However, surgical management of $\mathrm{BPH}$, including transurethral resection of the prostate (TURP) or open prostatectomy (OP), is indicated for patients with acute urinary retention, persistent or recurrent urinary tract infections, significant hemorrhage from the prostate, bladder calculi, ongoing symptoms refractory to medical therapy and/or renal failure as a result of chronic bladder obstruction (3); in some circumstances, it is performed according to patient's preference.

The choice of surgical options is important with respect to postoperative outcomes. TURP is associated with a short hospitalization and convalescence period, but increased rates of transurethral resection (TUR) syndrome and repeat surgery. On the other hand, OP is associated with a long hospitalization and convalescence period and increased bleeding rates but decreased retreatment rates because of more complete removal of the prostate (3). One of the most important parameters in choosing the treatment option is prostate volume (PV). Although the decision depends on surgical experience, OP should be considered when the estimated prostate weight is more than $75 \mathrm{~g}$ (3). Therefore, pre-operative accurate PV determination is important.

We aimed to identify the most suitable technique for PV measurement in order to choose the most suitable surgical technique, TURP or OP, by establishing the relationship of pre-surgical volume determination methods and the resected tissue weight (RTW).

\section{Materials and Methods}

The study was designed as a non-randomized prospective cohort analysis. A total of 60 men aged $49-95$ years with LUTS who were scheduled for TURP between September 2013 and December 2014 by one surgeon (AD) with a previous surgical experience of more than 500 TURP, were enrolled in this study. Following the Regional Ethics Committee approval, informed consent was obtained from all patients. Evaluation of patients included digital rectal examination, International Prostate Symptom Score (IPSS) and OoL assessments, urine analysis and urine culture, free and total prostate specific antigen (PSA) and free to total PSA ratio, uroflowmetry and post- voiding residual urine (PVR) determination, abdominal ultrasonography and transrectal ultrasonography (TRUS) on the table at the time of surgery, and cystoscopic evaluation for the measurement of the prostatic urethral length (PUL) and to understand if there is a urethral stricture or not before making the final decision about surgical technique. Inclusion criteria for surgical treatment were IPSS greater than 10, maximum flow rate (0max) less than $10 \mathrm{ml} / \mathrm{sec}$, PVR greater than $200 \mathrm{cc}$, a history of acute urinary retention more than 2 times, a history of recurrent urinary tract infection, and active macroscopic haematuria of prostatic origin not responsive to 5 alpha-reductase treatment. The exclusion criterion was presence of a urethral stricture.

PUL between the bladder neck and verumontanum was measured by cystoscopy. When the length of the resectoscope was not enough to reach the bladder neck, OP was performed.

Success criteria for this study were defined by Omax values and, a maximum urinary flow rate $(0 \max )$ greater than $15 \mathrm{ml} / \mathrm{sec}$ at the postoperative $3^{\text {rd }}$ month was evaluated as success.

The measurements were done in parallel. PV evaluation by preoperative abdominal ultrasonography and TRUS and PUL measurement by cystoscopy were done to determine the most accurate PV determination associated with the RTW.

We formed two groups with respect to PV according to abdominal ultrasonography and TUS measurements, which were less than or equal to $75 \mathrm{cc}$ and greater than $75 \mathrm{cc}$ for groups 1 and 2, respectively, and according to PUL less than or equal to $2.5 \mathrm{~cm}$ and longer than $2.5 \mathrm{~cm}$, for groups 1 and 2, respectively; statistical analyses were performed between the groups.

\section{Statistical Analysis}

The results are presented as mean \pm standard deviation. Data were analyzed using SPSS-16.0 for Windows (SPSS, Inc., Chicago, IL USA). Statistical analyses of the means of continuous variables were performed with the Student's t-test. The Pearson correlation test was used for determination of the correlation between prostatic volume measurements and RTW and then, data were analyzed using step-wise linear regression models. A value of less than 0.05 was considered statistically significant.

\section{Results}

A total of 60 men with LUTS with a mean age of $68.9 \pm 9.4$ years (minimum: 49; maximum: 95), who were going to be operated, were enrolled into the study. Pre-operative and post-operative IPSS, OoL scores, uroflowmetric parameters; Omax, average flow rate (Qave), and PVR and hemoglobin levels were analyzed using paired t-tests. All differences between the groups were statistically significant $(p<0.05)$ and the patients experienced 
significant improvements in all measures of $\mathrm{BPH}$-related signs and symptoms including IPSS, QoL, Omax, Qave, and PVR (Table 1).

In group 1, there were 37, 38 and 31 patients, for abdominal ultrasonographic PV, transrectal ultrasonographic PV and PUL measurements, respectively. In group 2, there were 23, 22 and 29 patients, respectively (Table 2). Operation times and RTWs were significantly different between the groups $(p<0.05)$ (Table 2).

The PVs, according to abdominal ultrasound and TRUS measurements were significantly different $(p<0.05)$ (Table 3 ).

Pearson's correlation was used to determine the relationship of RTW with PV measurements by abdominal ultrasonography and TRUS and PUL by cystoscopy. All correlations were significant but the strongest correlation was established for the TRUS measurements $(r=0.79 ; p<0.001)$ (Table 4).

The correlations between the prostatic measurements (which were obtained by abdominal ultrasonography, TRUS and cystoscopic PUL) and RTWs were analyzed using a linear regression stepwise method. Adjusted $\mathrm{R}$ square was established as $63.7 \%$, and the ANOVA produced significant results $(p<0.001)$. The coefficients of the abdominal and transrectal ultrasonographic PV and PUL were $0.127,0.287$ and 0.219 , respectively. According to these statistical results, the only variable that was consistently associated with RTW was TRUS measurements ( $<<0.001$ ) (Table 5).

The results of uroflowmetry have shown that the amount of resected tissue in each group was above the uroflowmetric success criteria (Table 6).

No serious complications, such as TUR syndrome, blood transfusion or incontinence were identified during the follow-up period.

\section{Discussion}

Despite many minimally invasive techniques for BPH management, TURP is still the standard of care for removal of tissue from the transition zone of the prostate. TURP has been performed in prostates of between 30 and $80 \mathrm{~mL}$ in approximately 95\% of the cases (2). However, there is no strong

Table 1. Pre-operative and post-operative results with regard to some parameter

\begin{tabular}{|l|l|l|l|}
\hline Parameters & $\begin{array}{l}\text { Pre-operative } \\
\text { results }\end{array}$ & $\begin{array}{l}\text { Post-operative } \\
\text { results }\end{array}$ & $p$ \\
\hline IPSS & $26.85 \pm 3.80$ & $4.93 \pm 2.14$ & 0.001 \\
\hline Quality of life & $4.9 \pm 0.11$ & $1.52 \pm 0.1$ & 0.001 \\
\hline Qmax $(\mathrm{m} / \mathrm{S})$ & $4.97 \pm 0.56$ & $22.76 \pm 0.73$ & 0.001 \\
\hline Qave $(\mathrm{ml} / \mathrm{S})$ & $2.25 \pm 0.16$ & $9.38 \pm 0.33$ & 0.001 \\
\hline PVR $(\mathrm{ml})$ & $306.161 \pm 161.24$ & $45.67 \pm 19.15$ & 0.001 \\
\hline Hb $(\mathrm{g} / \mathrm{d})$ & $13.9 \pm 1.98$ & $12.47 \pm 1.92$ & 0.001 \\
\hline
\end{tabular}

IPSS: International Prostate Symptom Score, Qmax: Maximum flow rate, Qave:

Average flow rate, PVR: Post-voiding residual, $\mathrm{Hb}$ : Hemoglobin evidence in the literature regarding the upper size limit of a prostate suitable for TURP $(2,4)$. OP should be considered when the prostate is estimated to have a volume of more than $80 \mathrm{~mL}$, as well as in some mandatory situations related to patients' co-morbidities, such as ankylosis of the hip or other orthopedic conditions preventing proper positioning for TURP, and in men with recurrent or complex urethral conditions, such as urethral stricture or previous hypospadias repair, in order to avoid urethral trauma associated with TURP $(3,4)$.

According to the European Association of Urology (EAU) guidelines, OP should be performed for prostates greater than $80 \mathrm{~mL}$ (4). The correct choice of surgical technique for prostatectomy depends on an accurate measurement of the PV. For that purpose, the features of prostatic measurement by various techniques, such as abdominal ultrasonography, TRUS, computed tomography (CT) and magnetic resonance imaging (MRI) have been studied in the literature.

The current study has shown that there is a significant difference in terms of PV between abdominal and transrectal measurements of the prostate. Our results yielded mean PVs of $67.81 \pm 33.4$ and $52.61 \pm 25.06$ for abdominal and transrectal measurements, respectively $(p<0.001)$. The finding presented in Table 3 that abdominal ultrasonography tends to result in an over-estimation of PV compared to TRUS is in accordance with clinical experience.

In order to understand which one of these methods should be preferred in decision making for the choice of surgical technique, the correlation between RTW and PV measurement techniques were investigated. Our data showed that TRUS measurements were most closely associated with RTW (Pearson's $r$ for TRUS $=0.79, p<0.001$; linear regression coefficient for TRUS $=0.287, p<0.001)$. On the other hand, the Pearson values between abdominal US and TRUS results are quite small. According to our results, TRUS measurements of PVs were less but operation times and RTWs were greater than abdominal ultrasonographic and PUL measurements. These results indicate that TRUS PV determination may be a useful guide for the choice of surgical technique.

Although some studies in the literature and the EAU guidelines define the upper limit of the PV for TURP as $80 \mathrm{~mL}(1,4,5)$, according to our results, the upper limit of PV for TURP depends on the size of the resectoscope. The maximum volume of the prostate in this study was $208 \mathrm{~mL}, 150 \mathrm{~mL}$ and $5 \mathrm{~cm}$ for abdominal ultrasonography, TRUS and PUL measurements, respectively. TURP was successfully performed for a case in which a total of $51 \mathrm{~g}$ of prostatic tissue was resected in 100 minutes without any serious complications such as TUR syndrome or blood transfusion. There were 22 patients who had prostates greater than $75 \mathrm{~mL}$ according to the TRUS measurements; their mean operation time was $71.11 \pm 16.72 \mathrm{~min}$ and the mean RTW was $33.11 \pm 13.56 \mathrm{~g}$. In this study, the results of uroflowmetric parameters in those who had prostates greater than $75 \mathrm{~mL}$ showed that TURP can be performed successfully in this group.

Table 2. Comparison of prostatic size measurements in terms of operation time and resected tissue weight according to group

\begin{tabular}{|c|c|c|c|c|c|c|c|}
\hline \multirow[t]{2}{*}{ Method } & \multicolumn{2}{|c|}{ Prostatic measurements } & \multicolumn{2}{|c|}{ Operation time (minimum) } & \multicolumn{3}{|c|}{ Resected tissue weight (g) } \\
\hline & Group 1 & Group 2 & Group 1 & Group 2 & Group 1 & Group 2 & $\mathrm{p}$ \\
\hline Abdominal ultrasonography & $\begin{array}{l}48.7 \pm 14.1 \\
\text { сc }\end{array}$ & $\begin{array}{l}98.2 \pm 32.4 \\
\text { cC }\end{array}$ & $\begin{array}{l}48.2 \pm 10.4 \\
n=37\end{array}$ & $\begin{array}{l}65 \pm 17.0 \\
n=23\end{array}$ & $16.3 \pm 5.39$ & $28.6 \pm 21.8$ & 0.001 \\
\hline Transrectal ultrasonography & $\begin{array}{l}38.0 \pm 12.6 \\
c c\end{array}$ & $\begin{array}{l}75.6 \pm 22.7 \\
c c\end{array}$ & $\begin{array}{l}52.2 \pm 13.89 \\
n=38\end{array}$ & $\begin{array}{l}71.11 \pm 16.72 \\
n=22\end{array}$ & $17.66 \pm 5.23$ & $33.11 \pm 13.56$ & 0.001 \\
\hline Cystoscopic prostatic urethral length & $\begin{array}{l}2.05 \pm 0.37 \\
\mathrm{~cm}\end{array}$ & $\begin{array}{l}3.44 \pm 0.5 \\
\mathrm{~cm}\end{array}$ & $\begin{array}{l}44.76 \pm 9.8 \\
n=31\end{array}$ & $\begin{array}{l}60.79 \pm 15.6 \\
n=29\end{array}$ & $13.95 \pm 4.35$ & $23.37 \pm 9.08$ & 0.001 \\
\hline
\end{tabular}


Table 3. Comparison of abdominal and transrectal

ultrasonography measurements in terms of prostatic size

\begin{tabular}{|l|l|l|l|}
\hline Parameter & $\begin{array}{l}\text { Abdominal } \\
\text { ultrasonographic } \\
\text { measurement }\end{array}$ & $\begin{array}{l}\text { TRUS } \\
\text { measurement }\end{array}$ & $p$ \\
\hline Prostatic size (cc) & $67.81 \pm 33.4$ & $52.61 \pm 25.06$ & 0.001 \\
\hline \multicolumn{4}{|l}{ TRUS: Transrectal ultrasonography } \\
\hline
\end{tabular}

Table 4 . The correlation between prostatic size measurements and resected tissue weight according to the measurement methods

\begin{tabular}{|l|l|l|}
\hline & Pearson's & $p$ \\
\hline $\begin{array}{l}\text { Abdominal ultrasonography - resected tissue } \\
\text { weight }\end{array}$ & 0.77 & 0.001 \\
\hline TRUS - Resected tissue weight & 0.79 & 0.001 \\
\hline $\begin{array}{l}\text { Cystoscopic prostatic urethral length - resected } \\
\text { tissue weight }\end{array}$ & 0.7 & 0.001 \\
\hline TRUS: Transrectal ultrasonography & \multicolumn{3}{|l}{} \\
\hline
\end{tabular}

Table 5. The correlation of the prostatic measurements with linear regression

\begin{tabular}{|l|l|l|}
\hline Prostatic measurements & $\begin{array}{l}\text { Coefficient of linear } \\
\text { regression }\end{array}$ & $p$ \\
\hline Abdominal ultrasonography & 0.127 & 0.64 \\
\hline Transrectal ultrasonography & 0.287 & 0.001 \\
\hline Cystoscopic prostatic urethral length & 0.219 & 0.09 \\
\hline
\end{tabular}

Dependent variable: Resected tissue weight, adjusted R square: 63.7\%, ANOVA: $p<0.001$

Table 6 . The results of uroflowmetric parameters at the postoperative $3^{\text {rd }}$ month $(p<0.05)$

\begin{tabular}{|l|l|l|l|}
\hline $\begin{array}{l}\text { Uroflowmetric } \\
\text { parameters }\end{array}$ & $\begin{array}{l}\text { Group } 1 \\
\mathrm{n}=38\end{array}$ & $\begin{array}{l}\text { Group 2 } \\
\mathrm{n}=22\end{array}$ & $\mathrm{p}$ \\
\hline Qmax $(\mathrm{mL} / \mathrm{sec})$ & $23.08 \pm 6.45$ & $22.22 \pm 4.11$ & 0.58 \\
\hline Qave $(\mathrm{ml} / \mathrm{sec})$ & $9.5 \pm 2.87$ & $9.04 \pm 2.12$ & 0.44 \\
\hline PVR $(\mathrm{mL})$ & $43.2 \pm 19.2$ & $48.63 \pm 18.7$ & 0.36 \\
\hline Omax: Maximum flow rate, Qave: Average flow rate, PVR: Post-voiding residual \\
\hline
\end{tabular}

According to a study by Aus et al. (6), TRUS successfully estimated PV, similar to our results. In addition, the transition zone volume predicted the expected resection weight of adenomas and, to some extent, the operation time and blood loss. According to their conclusion, these calculations may be used for more accurate pre-operative planning.

Tewari et al. (7) have also recommended TRUS measurements based on the results of their study. They compared PVs between TRUS and MRI measurements and their results showed that TRUS was as accurate as MRI (8).

PV is an important parameter for guiding the management of patients with BPH and delivering clinical trial endpoints. According to our results, RTW is most closely associated with TRUS measurements. In order to avoid the discomfort of TRUS during probe insertion, it can be performed just before the surgery under anesthesia.

\section{Study Limitations}

Weaknesses of the study: The choice of RTW as the gold standard is understandable from a practical perspective, but is certainly not infallible as RTW is in large part affected by intraoperative factors including bleeding and surgeon experience. Other reference standards such as total PV as measured by CT scan, MRI, or pathological measurement following OP should be discussed.

\section{Conclusion}

TRUS measurements of PVs better correlate with RTW than those of the abdominal ultrasonographic and cystoscopic PUL. For that reason, TRUS measurements of PV are more suitable than abdominal and cystoscopic PUL measurements with respect to choosing the most suitable surgical technique.

\section{Ethics}

Ethics Committee Approval: Following the Regional Ethics Committee approval, Informed Consent: Informed consent was obtained from all patients.

Peer-review: Internal peer-reviewed.

\section{Authorship Contributions}

Concept: Aslan Demir, Design: Aslan Demir, Data Collection or Processing: Aslan Demir, Mert Ali Karadağ, Kürşat Çeçen, Analysis or Interpretation: Aslan Demir, Mert Ali Karadağ, Kürşat Çeçen, Literature Research: Aslan Demir, Writing: Aslan Demir, Levent Türkeri.

Conflict of Interest: No conflict of interest was declared by the authors. Financial Disclosure: The authors declared that this study has received no financial support.

\section{References}

1. Kim JH, Park JY, Shim JS, Lee JG, Moon du G, Yoo JW, Choi H, Bae JH. Comparison of outpatient versus inpatient transurethral prostate resection for benign prostatic hyperplasia: Comparative, prospective bi-centre study. Can Urol Assoc J 2014;8:E30-35

2. Trumbeckas $D$, Milonas $D$, Jievaltas $M$, Matjosaitis $A$, Kincius $M$, Grybas $A$, Kopustinskas V. Importance of prostate volume and urinary flow rate in prediction of bladder outlet obstruction in men with symptomatic benign prostatic hyperplasia. Cent European J Urol 2011;64:75-79.

3. Han M, Partin AW. Retropubic and Suprapubic Open Prostatectomy. In: Kavoussi LR NA, Partin AW, Peters CA. Campbell-Walsh Urology, Elsevier, Saunders, 2012.

4. Gravas S, Bachmann A, Descazeaud A, Drake M, Gratzke C, Madersbacher $S$, Mamoulakis $C$, Oelke M, KAO. T. EAU guideline on: Management of Nonneurogenic Male Lower Urinary Tract Symptoms (LUTS), incl. Benign Prostatic Obstruction (BPO). Association of Urology Guidelines, 2014, pp. 62-70.

5. Karaman Ml, Kaya C, Ozturk M, Gurdal M, Kirecci S, Pirincci N. Comparison of transurethral vaporization using PlasmaKinetic energy and transurethral resection of prostate: 1-year follow-up. J Endourol 2005;19:734-737.

6. Aus $G$, Bergdahl $S$, Hugosson J, Norlen L. Volume determinations of the whole prostate and of adenomas by transrectal ultrasound in patients with clinically benign prostatic hyperplasia: correlation of resected weight, blood loss and duration of operation. Br J Urol 1994;73:659-663.

7. Tewari $A$, Indudhara $R$, Shinohara $K$, Schalow $E$, Woods $M$, Lee $R$, Anderson $C$, Narayan $P$. Comparison of transrectal ultrasound prostatic volume estimation with magnetic resonance imaging volume estimation and surgical specimen weight in patients with benign prostatic hyperplasia. J Clin Ultrasound 1996;24:169-174.

8. Grossfeld GD, Coakley FV. Benign prostatic hyperplasia: clinical overview and value of diagnostic imaging. Radiol Clin North Am 2000;38:31-47. 